\title{
Prehospital Damage Control: The Management of Volume, Temperature... and Bleeding!
}

\author{
Control de Daños Prehospitalario: ¡Para Los \\ Cristaloides, Para La Hipotermia Y...! ¡Para El \\ Sangrado!
}

\author{
Juan José Meléndez-Lugo ${ }^{1}$ (D) Yaset Caicedo ${ }^{\text {(D) }}$ Mónica Guzmán-Rodríguez ${ }^{3}$ (D) José \\ Julián Serna ${ }^{4,5,6,7}$ (D) Juliana Ordoñez ${ }^{5}$ (D) Edison Angamarca ${ }^{8}$ (D) Alberto García ${ }^{4,5,6}$ (D) Luis \\ Fernando Pino ${ }^{5,7}$ (D) Laureano Quintero ${ }^{5,9}$ Michael W. Parra ${ }^{10}$ Carlos A. Ordoñez ${ }^{4,5,6}$ \\ ordonezcarlosa@gmail.com, carlos.ordonez@fvl.org.co
}

1 Hospital Rafael Angel Calderon Guardia, Department of Surgery, San José, Costa Rica. 2 Fundación Valle del Lili, Centro de Investigaciones Clínicas (CIC), Cali, Colombia,3 Universidad de Chile, Instituto de Ciencias Biomédicas, Facultad de Medicina, Santiago de Chile, Chile.4 Fundación Valle del Lili, Department of Surgery, Division of Trauma and Acute Care Surgery, Cali, Colombia.5 Universidad del Valle, Facultad de Salud, Escuela de Medicina, Sección de Cirugía de Trauma y Emergencias, Cali Colombia, 6 Universidad Icesi, Cali, Colombia. 7 Hospital Universitario del Valle, Sección de Cirugía de Trauma y Emergencias, Cali, Colombia, 8 Hospital UTPL, Department of Surgery, Loja, Ecuador. 9 Centro Médico Imbanaco, Cali, Colombia.10 Broward General Level I Trauma Center, Department of Trauma Critical Care, Fort Lauderdale, FL, USA

Citation: Meléndez LJJ, Caicedo Y, Guzmán RM, Serna JJ, Ordoñez J, Angamarca E, García A, Pino LF, Quintero L, Parra MW, Ordoñez CA Prehospital Damage Control: The Management of Volume, Temperature... and Bleeding! Colomb Med (Cali). 2020;

51(4):e-2014486 http://doi. org/10.25100/cm.v51i 4.4486

Received : 21 Jul 2020

Revised : 11 Sep 2020

Accepted : 20 Dec 2020

Published: 30 Dec 2020

Keywords:

Trauma; Prehospital care; Damage Control; hemorrhage; Tourniquets; Shock; Hemorrhagic; Crystalloid Solutions; Hypothermia; Hemostatic Techniques; Blood Volume; Emergency Medical Services; Compartment Syndromes; Reperfusion

Palabras clave:

Trauma; Atención prehospitalaria; control de daños; hemorragia; hipotermia; Torniquetes; Choque hemorrágico; Soluciones cristaloides; Hipotermia; Vasoconstricción; Sangrado

\section{Abstract}

Damage control resuscitation should be initiated as soon as possible after a trauma event to avoid metabolic decompensation and high mortality rates. The aim of this article is to assess the position of the Trauma and Emergency Surgery Group (CTE) from Cali, Colombia regarding prehospital care, and to present our experience in the implementation of the "Stop the Bleed" initiative within Latin America. Prehospital care is phase 0 of damage control resuscitation. Prehospital damage control must follow the guidelines proposed by the "Stop the Bleed" initiative. We identified that prehospital personnel have a better perception of hemostatic techniques such as tourniquet use than the hospital providers. The use of tourniquets is recommended as a measure to control bleeding. Fluid management should be initiated using low volume crystalloids, ideally $250 \mathrm{cc}$ boluses, maintaining the principle of permissive hypotension with a systolic blood pressure range between $80-$ and $90-\mathrm{mm} \mathrm{Hg}$. Hypothermia must be management using warmed blankets or the administration of intravenous fluids warmed prior to infusion. However, these prehospital measures should not delay the transfer time of a patient from the scene to the hospital. To conclude, prehospital damage control measures are the first steps in the control of bleeding and the initiation of hemostatic resuscitation in the traumatically injured patient. Early interventions without increasing the transfer time to a hospital are the keys to increase survival rate of severe trauma patients. 
Copyright: @ 2020 Universidad del Valle.

(c) $($ )

Conflict of Interest: None

Corresponding author:

Carlos A. Ordonez, MD, FACS. Division of Trauma and Acute Care Surgery, Department of Surgery. Fundación Valle del Lili. Cali, Colombia; Division of Trauma and Acute Care Surgery, Department of Surgery, Universidad del Valle, Cali, Colombia; Universidad Icesi, Cali, Colombia. Email: ordonezcarlosa@ gmail.com, carlos.ordonez@fvl.org.co

\section{Resumen}

La resucitación en el control de daños debe iniciarse lo más rápido posible después de presentado el evento traumático para evitar descompensación metabólica y aumento de la mortalidad. El objetivo de este artículo es sustentar nuestro enfoque respecto a la atención prehospitalaria y presentar nuestra experiencia en la implementación de la iniciativa "Stop the Bleed" en Latinoamérica. La atención prehospitalaria es la fase Cero de la resucitación del control de daños. Por medio de la implementación de la iniciativa "Stop the Bleed" se identificó que el personal prehospitalario tiene una mejor percepción sobre el uso de técnicas hemostáticas como el torniquete que el personal hospitalario. Se recomienda el uso de torniquetes como medida de control de sangrado en extremidades. El manejo de líquidos debe realizarse usando cristaloides a bajos volúmenes, con bolos de $250 \mathrm{~mL}$ para cumplir el principio de la hipotensión permisiva con un rango entre 80 y $90 \mathrm{~mm} \mathrm{Hg}$ de presión arterial sistólica. Se deben realizar medidas para evitar la hipotermia como el uso de sábanas térmicas o paso de líquidos calientes. Estas medidas no deben retrasar en ningún momento el tiempo de traslado para recibir la atención hospitalaria.

En conclusión, la atención prehospitalaria es el paso inicial para garantizar las primeras medidas de control de sangrado y de resucitación hemostática de los pacientes. Realizar intervenciones tempranas sin acortar el tiempo de traslado a la atención hospitalaria son las claves para aumentar la tasa de supervivencia.

\section{Remark}

\section{1)Why was this study conducted?}

Damage control resuscitation should be initiated as soon as possible after a trauma event to avoid metabolic decompensation and high mortality rates. The aim of this article is to describe the pre-hospital attention principles and our experience regarding Stop the Bleed initiative within Latin America.

\section{2) What were the most relevant results of the study?}

The use of tourniquets is recommended as a measure to control bleeding. Fluid management should be initiated using low volume crystalloids keeping the permissive hypotension principle. Hypothermia must be management using warmed blankets or the administration of intravenous fluids warmed prior to infusion. However, these prehospital measures should not delay the transfer time of a patient from the scene to the hospital.

\section{3) What do these results contribute?}

Prehospital damage control measures are the first steps in the control of bleeding and the initiation of hemostatic resuscitation in the traumatically injured patient 


\section{Introduction}

Severe traumatic hemorrhage is the leading preventable cause of death among young adults ${ }^{1,2}$. The early care of a trauma patient can be challenging, with a high mortality rate especially in the first two hours after injury, which makes the bleeding control a time-sensitive condition ${ }^{3,4}$. Damage control resuscitation (DCR) is an effort to understand the metabolic response to trauma and what measures can be implemented to improve this physiological deterioration. The concept of DCR evolved from the principles of damage control surgery ${ }^{5}$. In 2001, phase 0 of damage control surgery was introduced, focusing on early damage control measures that can be taken in the prehospital setting ${ }^{6}$. However, it is still an open debate which measures should be implemented, especially those involving bleeding control in the prehospital setting $^{7-10}$. This is why, the Trauma and Emergency Surgery Group (CTE) group from Cali, Colombia has developed a campaign in Colombia and other Latin American countries including Costa Rica and Ecuador, with the aim of teaching basic damage control techniques for health care provides or community personnel through the Stop the Bleed Course. The aim of this article is to state our position regarding prehospital care and damage control resuscitation, including our experience with the "Stop the Bleed" Campaign in Latin America.

This article is a consensus that synthesizes the experience earned during the past 30 years in trauma critical care management of the severely injured patient from the Trauma and Emergency Surgery Group (CTE) of Cali, Colombia which is made up of experts from the University Hospital Fundación Valle del Lili, the University Hospital del Valle "Evaristo García", the Universidad del Valle and Universidad Icesi, the Asociación Colombiana de Cirugia, the Pan-American Trauma Society and the collaboration of national and international specialists of the United States of America and Latin America.

\section{Epidemiology}

Trauma is one of the leading causes of death worldwide. According to the World Health Organization (WHO), 4.9 million people died in 2016 due to any type of trauma ${ }^{11}$. Mortality rates were higher in low-income countries, mainly due to traffic road accidents. In Colombia, the Departamento Administrativo Nacional de Estadistica (DANE) ${ }^{12}$ reported that the trauma is the main cause of death among young adults and the second leading cause of death in general population with a total of 34,216 deaths in $2007.54 \%$ of all patients who died between 1998 and 2011, were considered to died due to preventable causes, the most common trauma mechanism was gunshot wounds, followed by stab wounds, and traffic road accidents ${ }^{12,13}$.

The $50 \%$ of patients with severe hemorrhage do not receive timely healthcare and die before hospital admission. In 2014, 1848 trauma-related deaths were analyzed, finding that 305 cases were related to non-controlled hemorrhage. Uncontrolled hemorrhage was identified as the cause of death in 305 patients. $44.9 \%$ of these deaths were attributed to potentially preventable hemorrhage. $35.8 \%$ of these deaths occurred in the prehospital setting and $20.4 \%$ occurred within the first hour prior to admission. Trauma to a non-compressible body zone was present in $74.5 \%$ of these deaths, $21.6 \%$ occurred in the chest, $38.2 \%$ in the chest and abdomen, $15.7 \%$ in the abdomen alone and $24.5 \%$ in another area ${ }^{14}$.

\section{Pathophysiology}

Damage control resuscitation in a prehospital setting focuses on the aggressive prevention and treatment of the lethal triad of hypothermia, acidosis, and coagulopathy described by Moore et al. in $1996^{15}$, and recently expanded by Ditzel et al. to lethal diamond with the inclusion of hypocalcemia ${ }^{16}$. Traumatized patients who develop the lethal triad of death have a mortality rate up to $50 \%{ }^{17}$. Both hypothermia and acidosis cause coagulopathy by hampering platelet aggregation, decreasing the activity of clotting factors, and interfering with fibrinolysis ${ }^{18,19}$. However, the observed coagulopathy is not only attributed to metabolic decompensation, but also exacerbated by some resuscitation measures, such as excessive crystalloid administration ${ }^{19,20}$. 
Peripheral vasoconstriction allows a transient hemostasis due to the preservation of circulating volume, which is presumably being lost through the injured tissue ${ }^{21,22}$. This effect of trauma has been described in two moments: the first hit, which encompasses the local and systemic reactions caused by the direct energy transferred by the trauma that causes bleeding, hypoxia and tissue damage; the second hit encompasses secondary reactions to injury and metabolic response, including ischemia/reperfusion phenomena, compartment syndrome, infections, among others ${ }^{23,24}$.

\section{Initial Approach}

The initial assessment of the trauma patient allows to determine the patient's condition, as well as the best timely decisions to be made for subsequent management. According to the Prehospital Trauma Life Support (PHTLS), the initial assessment of the patient should be focused on ${ }^{25}$ :

1. Control of major bleeding $(\mathrm{X})$

2. Airway (A)

3. Breathing (B)

4. Circulation $(\mathrm{C})$

5. Disability (D)

6. Exposure and control of the environment (E)

The first critical step of prehospital care is to be able to identify if the patient has lifethreatening bleeding, which can be challenging on initial evaluation. Given this, initiatives have been undertaken to develop tools to detect hemorrhagic shock in a timely fashion, and to take initial steps to slow hemorrhage on the field. The "Stop the Bleed" campaign recommends an estimation of the patient's volume and hemodynamic status through recognition of specific clinical signs ${ }^{26}$. These clinical signs should be evaluated together, rather than relying on only one parameter to determine a patient's hemodynamic status. The proportion of blood lost in relation to the patient's blood volume can, in early stages, induce vital sign changes such as high heart rate, changes in the respiratory pattern or quality of the pulse wave. As blood loss exceeds $15 \%$ of blood volume, tachypnea and mucocutaneous pallor are often evident, without changes in blood pressure. With a loss of more than 30\%, hypotension, altered mental status and reduced urine output can occur. As such, if a provider waits for hypotension to suspect that a patient is hemodynamically decompensating, it may already be too late for any intervention ${ }^{27,28}$. Therefore, it is recommended to have the systolic blood pressure (SBP) as a reference, with the alarm point being a SBP of less than $90 \mathrm{mmHg}{ }^{25,29}$,

\section{Initial Management}

Phase 0 of DCR, also known as remote DCR, focuses on prehospital interventions for patients with severe trauma. The measures that should be carried out regardless of the resources or geographic location should include bleeding control, permissive hypotension, fluid therapy, temperature control and immediate transfer to a hospital where definitive care can be provided.

\section{Bleeding Control}

In a patient with active hemorrhage, bleeding control is the most important intervention. If bleeding persists, metabolic recovery is not possible, which could exacerbate the patient's metabolic debt and ultimately lead to exsanguination ${ }^{30}$.

The "Stop the Bleed" campaign convened by the National Security Council at the White House of the United States in collaboration with the American College of Surgeons in 2015 was a call to action ${ }^{31}$. The main objective of this campaign was to empower untrained people to act in the presence of victims of violent traumatic events with life-threatening bleeding by giving them the tools to stop the bleeding at the scene. The first step in bleeding control is identification of an external bleeding site followed by direct control. The first technique employed should be direct pressure. Pressure should be applied to the external bleeding site until it stops, ideally in a sustained manner, on a firm surface, with or without a dressing ${ }^{32,33}$. 
If despite direct pressure on the wound, bleeding does not stop, or if direct pressure is difficult to perform, for example, because a wounds involves a cavity or is at a site of union (such as the armpit, groin or neck), packing of the wound should be performed. This is achieved through the complete insertion of a clean cloth or dressing from the deepest to the most superficial part against resistance, filling the wound. This technique, however, should not replace direct pressure. While ideally a hemostatic dressing would be used as packing material in order to facilitate the formation of clot, any material can be used. Examples of hemostatic dressings include oxidized cellulose, fibrin glue, synthetic adhesives, as well as Zeolite or Chitosan, which are the latest generations of local hemostatic agents ${ }^{34}$.

For bleeding in the extremities and for cases that do not involve areas of union, tourniquet should be used as a first line intervention (Figure 1). Although its use has been controversial in the past, current evidence supports its prehospital use in victims of civilian trauma ${ }^{35,37}$. In these circumstances, tourniquets have proven to be effective in achieving temporary control of bleeding, with low complication rates. One of the main limitations regarding tourniquet placement is the lack of training. The "Stop the Bleed" course is aimed for the use of combat application tourniquets (CAT), with the caveat that the correct application of these tourniquets is not necessarily transferable to other types of commercially available tourniquets. The main indication for the use of tourniquets is major bleeding from the extremities. When placing a CAT, the following 5 important points should be considered (Figure 2) ${ }^{38,39}$ :

The Trauma and Emergency Surgery group in Cali (CTE), has been pioneer on the education of both medical and non-medical personnel through the "Stop the Bleed" course throughout Latin America, specifically in Colombia, Costa Rica, and Ecuador. In our first course, with the training of 265 people, we compared if there were any differences if the courses were dictated by surgeons or by medical students. Among personnel with prehospital training prior to the course only $84.2 \%$ reported knowing how to apply any bleeding control technique, and only $43.4 \%$ stated that they would place a tourniquet in case of bleeding, however, this perception changed after

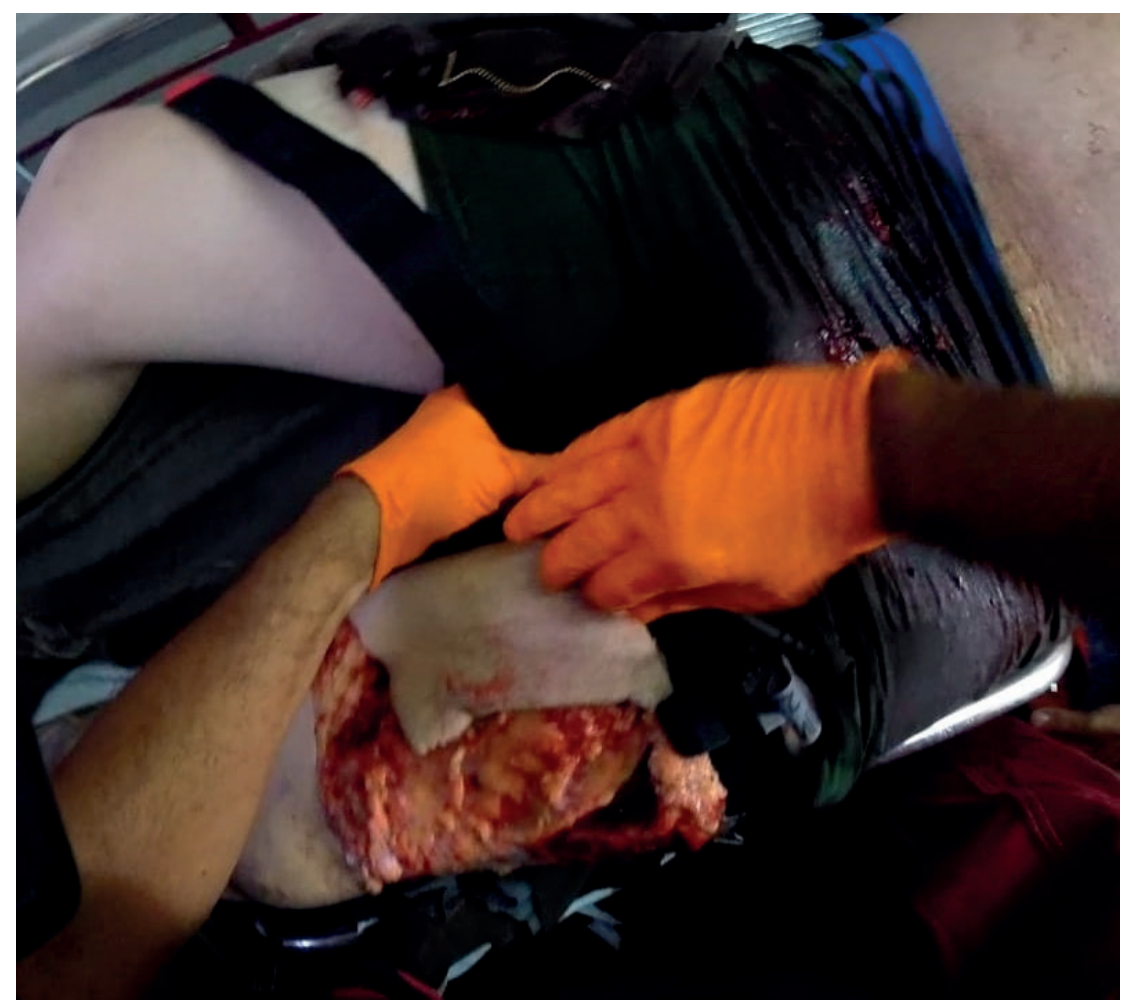

Figure 1. Combat Application Tourniquets being placed on a patient with extremity trauma at the scene. 


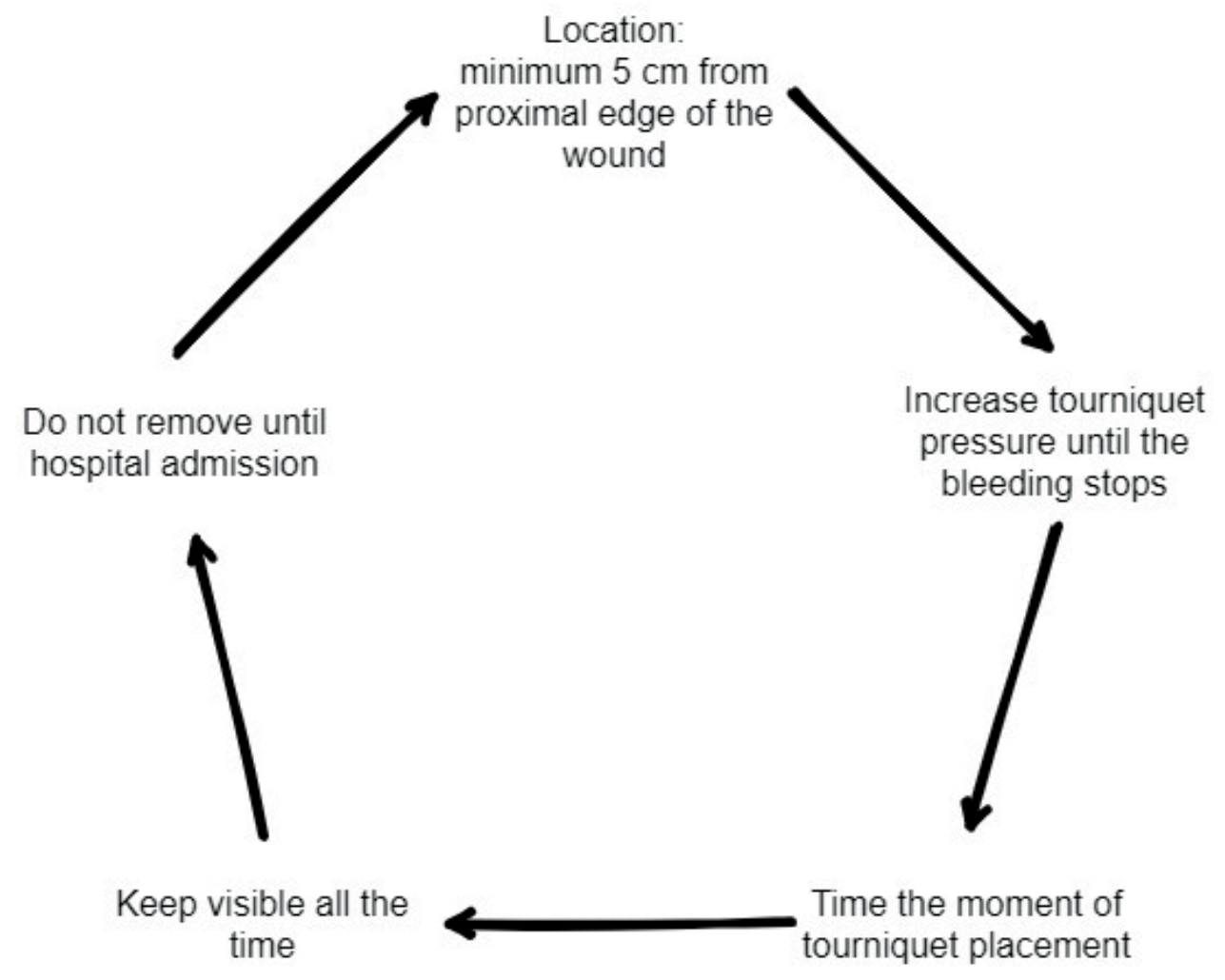

Figure 2. Five points to consider in the prehospital application of a tourniquet 38,39.

the course, when more than $90 \%$ stated that they would likely use a tourniquet. It was found that there was no significant difference between those trained by surgeons vs. those trained by medical students ${ }^{40,41}$. In subsequent analyses, we have also explored factors prior to the course that could be associated with correct use of bleeding control strategies on the field. It was identified that the number of previous trainings (having taken prior courses such as Basic Life Support, Advance Cardiovascular Life Support, PHTLS), having previously used the tourniquet, and being non-medical personnel were all factors associated with a greater probability of good use of a tourniquet. The association with nonmedical personnel and good tourniquet use may be due to the fact that tourniquet use has been taught as a harmful technique during medical education, a belief that has been contradicted with recent evidence.

Finally, to facilitate decision-making when managing a patient with bleeding in the prehospital setting, we propose the following management algorithm (Figure 3):

\section{Permissive Hypotension}

During World War I, Dr. Cannon observed that administering fluids to trauma patients in hemorrhagic shock could increase bleeding because of clot disruption due to an increase in blood pressure. However, only in the 1990s the concept of permissive hypotension was resume and studied ${ }^{42}$. The main objective of this strategy was to decrease the amount of fluids administered to a patient with massive bleeding while achieving surgical hemostasis, thereby maintaining only the minimum blood pressure necessary for the perfusion of vital organs. In 1994, Bickel and Mattox evaluated patients resuscitated with a high-volume crystalloid strategy vs. volume-restricted crystalloid strategy. They found an $8 \%$ reduction in mortality in hypotensive patients who were victims of penetrating torso trauma in the resuscitation group with volume restriction compared to the resuscitation group without fluid restriction ${ }^{43}$. However, these findings have been difficult to replicate in subsequent studies. In a 2002 study 


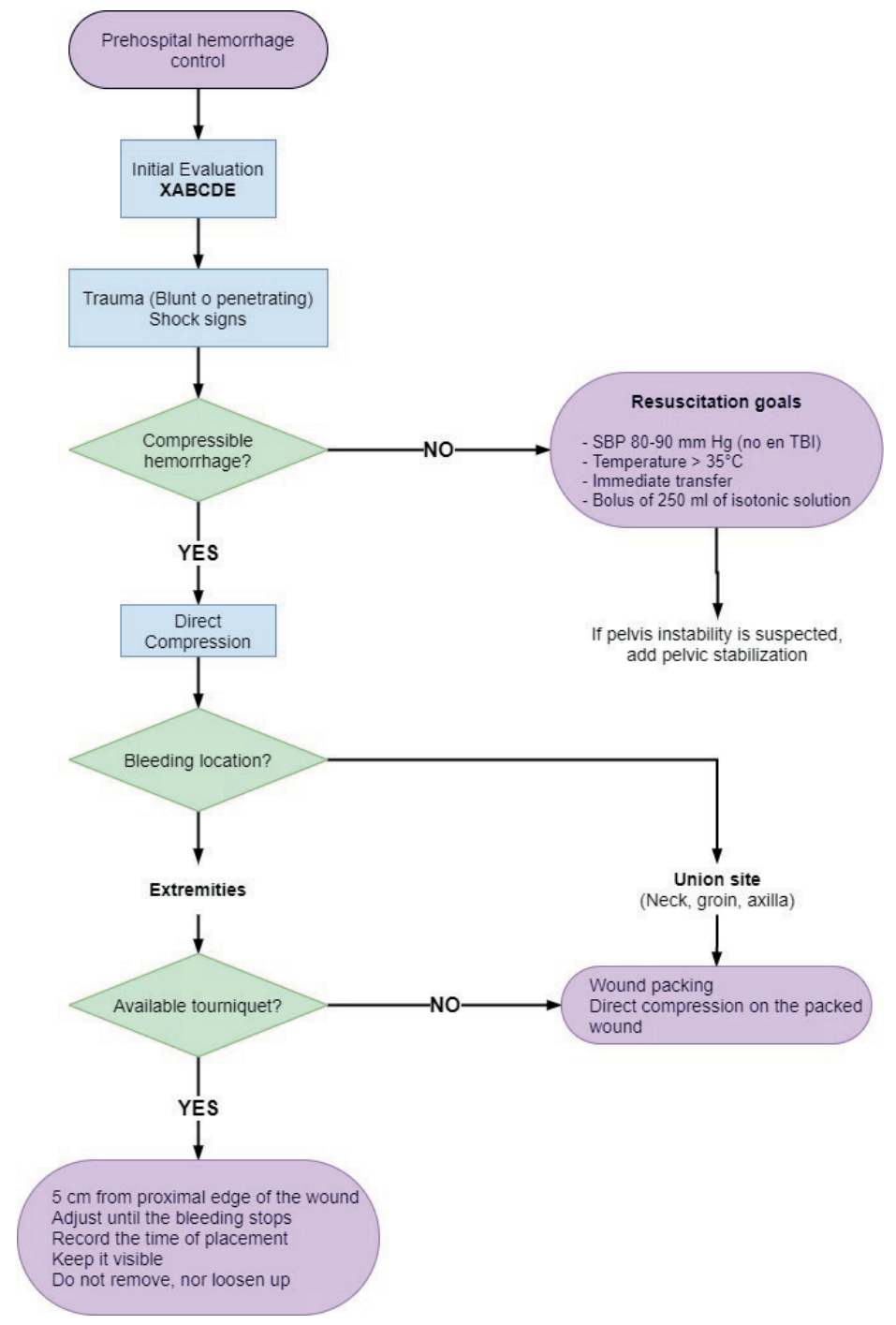

Figure 3. Management algorithm for prehospital hemorrhage control

by Dutton et al. ${ }^{44}$, it was found that titration of initial fluid therapy to a lower-than-normal SBP value during active bleeding did not affect mortality of patients who were victims of blunt or penetrating trauma. However, it is accepted that infusion should be maintained to keep blood pressure in the range that allows end-organ perfusion.

\section{Fluid Therapy}

It has been shown that the type of fluid used for resuscitation has a direct effect on clinical outcomes. There is sufficient evidence to justify the use of crystalloids, as neither colloids nor hypertonic solutions have shown to have a benefit when compared to the infusion of isotonic crystalloids ${ }^{45-49}$. The use of blood products such as plasma or even whole blood outside the hospital is not a widely available practice; consequently, it will not be discussed in this section. However, the authors acknowledge that the early control of bleeding and replacement of the lost volume with blood would improve clinical outcome.

Crystalloids are electrolyte-based solutions currently used as the first choice of resuscitation fluid prior to hospital admission. Normal saline $(0.9 \% \mathrm{NaCl})$ together with Lactate Ringers are the most frequently used crystalloids. One of the main limitations of their use as a resuscitation fluid is that they are very poor expanders of plasma volume, because only about $20 \%$ of the infused fluid remain in the intravascular space, and the rest, spread into the interstitial space ${ }^{50}$. 
Table 1. Clinical criteria to establish the goals of intravenous fluid therapy such as time to hospital arrival, mechanism of trauma, and traumatic brain injury ${ }^{51-55}$.

\begin{tabular}{ll}
\hline Parameter & Indication for iv infusion \\
\hline Time to hospital arrival & $>10-15 \mathrm{~min}$ of transport time \\
Mechanism of trauma & Penetrating trauma: $\mathrm{SBP}<60-70 \mathrm{mmHg}$ \\
& Blunt trauma: $\mathrm{SBP}<80-90 \mathrm{mmHg}$ \\
Traumatic brain injury (TBI) & Penetrating trauma $+\mathrm{TBI}$ SBP $<100-110 \mathrm{mmHg}$ \\
\hline
\end{tabular}

To help define situations in which patients with life-threatening bleeding may benefit from crystalloid infusion, the establishment of clear criteria that warrant prehospital resuscitation with intravenous fluid is required. Table 1 summarizes some parameters that can be taken into account when determining which patients could benefit from prehospital volume resuscitation ${ }^{51-55}$. It is important to recognize that guiding resuscitation using preset SBP values could lead to the administration of large volumes of crystalloid, which could have serious complications. The main side effects associated with the use of crystalloids include: increase in the bleeding as a consequence of clot disruption, dilutional coagulopathy, electrolyte disturbances, edema, end-organ dysfunction, fluid overload, limb and abdominal compartment syndrome, decreased wound healing, and increased mortality, among other cardiac, respiratory, gastrointestinal and immunological complications ${ }^{56-60}$.

To minimize the complications associated with excessive intravenous fluid administration, and to simplify the decision-making process as much as possible in the prehospital setting, our group, in accordance with international guidelines ${ }^{61,62}$ recommends administering crystalloids as boluses of $250 \mathrm{cc}$ at a time.

\section{Temperature Control}

Hypothermia is an important factor contributing to the worsening of coagulopathy, cardiac function, and metabolic acidosis. There are several potential causes of hypothermia in trauma patients, including: exposure to cold at the site of injury, administration of cold intravenous fluids, and metabolic disorders due to the trauma itself. Hypothermia can be classified into 3 categories: mild $\left(34-36^{\circ} \mathrm{C}\right)$, moderate $\left(34-32^{\circ} \mathrm{C}\right)$ and severe $\left(<32^{\circ} \mathrm{C}\right)^{8}$. Although, patients with the worst outcomes are those with temperatures of $32^{\circ} \mathrm{C}$ or less ${ }^{63}$, an increase in mortality can be noted in patients with temperatures lower than $35^{\circ} \mathrm{C}{ }^{64}$. Diverse strategies can be employed to maintain a core body temperature above $35^{\circ} \mathrm{C}$ in severely injured trauma patients, such as using heated blankets, warming of intravenous fluids to $39^{\circ} \mathrm{C}$ prior to infusion, and early control of hemorrhage.

\section{Immediate Transfer}

Prehospital personnel should never delay the transfer to the hospital, not even for resuscitative interventions on any patient with major bleeding, especially with non-compressible bleeding. Early transfer to the hospital is so important that some studies have found that even when transportation is not performed by emergency medical services, as long as it is immediate, there is an immediate benefit on mortality ${ }^{65,66}$. It is crucial that prehospital staff aim to shorten response time, scene time and transfer time to effectively give severe injured patients a timely intervention. The challenge for those delivering prehospital care is to identify circumstances that do justify aggressive out-of-hospital interventions such as tourniquet placement in patients with massive bleeding of an extremity, maintaining a patent airway or starting fluids in patients with crush injuries, among many others.

\section{The Future}

The CTE group from Cali, Colombia, is pioneer in innovation and care of trauma patients. As our experience grows with novel techniques such as the use of Resuscitative Endovascular Balloon Occlusion of the Aorta (REBOA), hemostatic resuscitation, and pharmacological 
supplements, efforts should be made to transfer some of these advances into the prehospital setting. We believe that technology like REBOA is not necessarily the future of trauma, but rather the present. It is important that trauma centers in our region begin to expand upon their own experience with such technologies. With an increasingly advanced world, we believe that stabilization protocols for prehospital personnel in our region, and the implementation of courses to teach basic skills such as arterial line placement in the common femoral artery are just around the corner. The future holds additional challenges as evidence grows around hemostatic resuscitation, supporting the use of whole blood inside and eventually outside the hospital. Finally, we must understand that time is essential in trauma and patients require aggressive and efficient management from the moment that injury occurs. To give our patients the best chance at survival, our trauma systems must be kept up-to-date with current technology, this is why, and especially for cases of long transfer time, we have to consider the implementation of some of these new techniques to improve patient outcomes ${ }^{67,68}$.

\section{Conclusion}

Prehospital care is the first step to guarantee bleeding control and hemostatic resuscitation of trauma patients. Early interventions without increasing transfer time to a hospital are the keys to increase the success rate of the other strategies used in damage control. Strategies like the "Stop the Bleed Campaign" can provide tools for non-medical personnel to perform early maneuvers that can make a difference and decrease mortality.

\section{References}

1. Kauvar DS, Lefering R, Wade CE. Impact of hemorrhage on trauma outcome: an overview of epidemiology, clinical presentations, and therapeutic considerations. J Trauma. 2006;60:S3-11. Doi: 10.1097/01.

ta.0000199961.02677.19.

2. Cothren CC, Moore EE, Hedegaard HB, Meng K. Trauma deaths by predominant mechanism. Brain Inj. 2002; 130(2): 328. 10.1016/j.jss.2005.11.484

3. Acosta MD, José A, Yang MD, Jack C, Winchell MD, Robert J, et al. Lethal injuries and time to death in a level I trauma center. J Am Coll Surg. 1998;186:528-33.

4. Cannon JW. Prehospital damage-control resuscitation. N Engl J Med. 2018;379:387-8. Doi: 10.1056/ NEJMe1805705.

5. Rotondo MF, Zonies DH. The damage control sequence and underlying logic. Surg Clin North Am. 1997;77:761-77.

6. Johnson JW, Gracias VH, Schwab CW, Reilly PM, Kauder DR, Shapiro MB, et al. Evolution in damage control for exsanguinating penetrating abdominal injury. J Trauma. 2001;51:261-71. Doi: 10.1097/00005373200108000-00007.

7. Kalkwarf KJ, Cotton BA. Resuscitation for Hypovolemic Shock. Surg Clin North Am. 2017;97:1307-21. Doi: 10.1016/j.suc.2017.07.011.

8. Kaafarani HMA, Velmahos GC. Damage control resuscitation in trauma. Scand J Surg. 2014;103:81-8. Doi: $10.1177 / 1457496914524388$.

9. Van PY, Holcomb JB, Schreiber MA. Novel concepts for damage control resuscitation in trauma. Curr Opin Crit Care. 2017;23:498-502. Doi: 10.1097/MCC.0000000000000455.

10. Lendrum R, Perkins Z, Chana M, Marsden M, Davenport R, Grier G, et al. Pre-hospital Resuscitative Endovascular Balloon Occlusion of the Aorta (REBOA) for exsanguinating pelvic haemorrhage. Resuscitation. 2019;135:6-13. Doi: 10.1016/j.resuscitation.2018.12.018. 
11. Mathers C, Stevens G, Hogan D, Mahanani WR, Ho J. Global and regional causes of death: patterns and trends, 2000-15. Dis. Control Priorities, Third Ed. (Volume 9) Improv. Heal. Reducing Poverty, The World Bank; 2017, p. 69-104. Doi: 10.1596/978-1-4648-0527-1_ch4.

12. DANE. Defunciones no fetales. DANE; 2019. Available from: https://www.dane.gov.co/index.php/ estadisticas-por-tema/salud/nacimientos-y-defunciones/defunciones-no-fetales

13. Ordoñez CA, Manzano-Nunez R, Naranjo MP, Foianini E, Cevallos C, Londoño MA, et al. Casualties of peace: An analysis of casualties admitted to the intensive care unit during the negotiation of the comprehensive Colombian process of peace. World J Emerg Surg. 2018;13:2. Doi: 10.1186/s13017-017-0161-2.

14. Kalkwarf KJ, Drake SA, Yang Y, Thetford C, Myers L, Brock M, et al. Bleeding to Death in a Big City: An Analysis of All Trauma Deaths From Hemorrhage in a Metropolitan Area Over One Year. J Trauma Acute Care Surg. 2020; 89(4):716-722. Doi: 10.1097/TA.0000000000002833.

15. Moore EE. Staged laparotomy for the hypothermia, acidosis, and coagulopathy syndrome. Am J Surg. 1996;172:405-10. Doi: 10.1016/S0002-9610(96)00216-4.

16. Ditzel RM, Anderson JL, Eisenhart WJ, Rankin CJ, DeFeo DR, Oak S, et al. A review of transfusion- And trauma-induced hypocalcemia: Is it time to change the lethal triad to the lethal diamond? J Trauma Acute Care Surg. 2020;88:434-9. Doi: 10.1097/TA.0000000000002570.

17. Mitra B, Tullio F, Cameron PA, Fitzgerald M. Trauma patients with the "triad of death." Emerg Med J. 2012;29:622-5. Doi: 10.1136/emj.2011.113167.

18. Martini WZ, Pusateri AE, Uscilowicz JM, Delgado A V., Holcomb JB, Tyburski JG, et al. Independent contributions of hypothermia and acidosis to coagulopathy in swine. J Trauma - Inj Infect Crit Care. 2005;58:1002-10. Doi: 10.1097/01.TA.0000156246.53383.9F.

19. Wolberg AS, Meng ZH, Monroe DM, Hoffman M. A systematic evaluation of the effect of temperature on coagulation enzyme activity and platelet function. J Trauma. 2004;56:1221-8. Doi: 10.1097/01. TA.0000064328.97941.FC.

20. Cohen MJ, Kutcher M, Redick B, Nelson M, Call M, Knudson M, et al. Clinical and mechanistic drivers of acute traumatic coagulopathy. J Trauma Acute Care Surg. 2013;75:40-7. Doi: 10.1097/TA.0b013e31828fa43d.

21. Harris T, Davenport R, Mak M, Brohi K. The Evolving Science of Trauma Resuscitation. Emerg Med Clin North Am. 2018;36:85-106. Doi: 10.1016/j.emc.2017.08.009.

22. Brohi K, Singh J, Heron M, Coats T. Acute Traumatic Coagulopathy. J Trauma. 2003;54:1127-30. Doi: 10.1097/01.TA.0000069184.82147.06.

23. Keel M, Trentz O. Pathophysiology of polytrauma. Injury. 2005;36:691-709. Doi: 10.1016/j.injury.2004.12.037.

24. Keel M, Labler L, Trentz O. "Damage control" in severely injured patients: Why, when, and how? Eur J Trauma. 2005;31:212-21. Doi: 10.1007/s00068-005-2034-8.

25. Teuben M, Löhr N, Jensen KO, Brüesch M, Müller S, Pfeifer R, et al. Improved pre-hospital care efficiency due to the implementation of pre-hospital trauma life support (PHTLS(r)) algorithms. Eur J Trauma Emerg Surg. 2020; 46(6):1321-1325. Doi: 10.1007/s00068-019-01141-1.

26. Goolsby C, Jacobs L, Hunt RC, Goralnick E, Singletary EM, Levy MJ, et al. Stop the Bleed Education Consortium: Education program content and delivery recommendations. J Trauma Acute Care Surg. 2018;84:205-10. Doi: 10.1097/TA.0000000000001732.

27. Wo CCJ, Shoemaker WC, Appel PL, Bishop MH, Kram HB, Hardin E. Unreliability of blood pressure and heart rate to evaluate cardiac output in emergency resuscitation and critical illness. Crit Care Med. 1993;21:21823. Doi: $10.1097 / 00003246-199302000-00012$. 
28. Mutschler M, Nienaber U, Brockamp T, Wafaisade A, Wyen H, Peiniger S, et al. A critical reappraisal of the ATLS classification of hypovolaemic shock: Does it really reflect clinical reality? Resuscitation. 2013;84:309-13. Doi: 10.1016/j.resuscitation.2012.07.012.

29. Crerar-Gilbert A. Advanced trauma life support. Anaesthesia. 1993; 48(5): 441. Doi: 10.1111/j.13652044.1993.tb07025.x.

30. Dutton RP. Haemostatic resuscitation. Br J Anaesth. 2012;109:39-46. Doi: 10.1093/bja/aes389.

31. Moore K. Stop the Bleeding: The Hartford Consensus. J Emerg Nurs. 2017;43:482-3. Doi: 10.1016/j. jen.2017.06.009.

32. Zideman DA, De Buck EDJ, Singletary EM, Cassan P, Chalkias AF, Evans TR, et al. European resuscitation council guidelines for resuscitation 2015 section 9. first aid. Resuscitation. 2015;95:278-87. Doi: 10.1016/j. resuscitation.2015.07.031.

33. Singletary EM, Charlton NP, Epstein JL, Ferguson JD, Jensen JL, MacPherson Al, et al. Part 15: First aid: 2015 American Heart Association and American red cross guidelines update for first aid. Circulation. 2015;132:S574-89. Doi: 10.1161/CIR.0000000000000269.

34. Recinos G, Inaba K. Local and systemic hemostatics in trauma?: a review Travmada lokal ve sistemik hemostatik ajanlar?: Derleme yaz s. Turkish J Trauma Emerg Surg. 2008;14:175-81.

35. Hsu YT, Chang DC, Perez NP, Westfal ML, Kelleher CM, Sacks CA, et al. Civilian firearm-related injuries: How often is a tourniquet beneficial? Ann Surg. 2020;271:E12-3. Doi: 10.1097/SLA.0000000000003622.

36. Teixeira PGR, Brown CVR, Emigh B, Long M, Foreman M, Eastridge B, et al. Civilian Prehospital Tourniquet Use Is Associated with Improved Survival in Patients with Peripheral Vascular Injury. J Am Coll Surg. 2018;226:769-776.e1. Doi: 10.1016/j.jamcollsurg.2018.01.047.

37. Inaba K, Siboni S, Resnick S, Zhu J, Wong MD, Haltmeier T, et al. Tourniquet use for civilian extremity trauma. J Trauma Acute Care Surg. 2015;79:232-7. Doi: 10.1097/TA.0000000000000747.

38. Goralnick E, Chaudhary MA, McCarty JC, Caterson EJ, Goldberg SA, Herrera-Escobar JP, et al. Effectiveness of instructional interventions for hemorrhage control readiness for laypersons in the public access and tourniquet training study (PATTS) a randomized clinical trial. JAMA Surg. 2018;153:791-9. Doi: 10.1001/ jamasurg.2018.1099.

39. Galante JM. Using tourniquets to stop bleeding. JAMA. 2017;317:1490. Doi: 10.1001/jama.2015.8581.

40. Orlas CP, Parra MW, Herrera-Escobar JP, Meléndez JJ, Serna JJ, Angamarca E, et al. The Challenge of Implementing the "Stop the Bleed" Campaign in Latin America. J Surg Res. 2020;246:591-8. Doi: 10.1016/j. jss.2019.09.042.

41. Orlas CP, Manzano-Núñez R, Pablo Herrera J, García AF, Chica J, Salazar CJ, et al. Control prehospitalario de la hemorragia en pacientes de trauma: una estrategia de prevención secundaria factible para países de bajos y medianos ingresos. Rev Colomb Cirugía. 2018;33:371-9. Doi: 10.30944/20117582.84.

42. Cannon E. Nature and treatment of wound shock and allied conditions. JAMA. 1918;70:520. Doi: 10.1001/ jama.1918.02600080022008.

43. Bickell WH, Wall MJ, Pepe PE, Martin RR, Ginger VF, Allen MK, et al. Immediate versus Delayed Fluid Resuscitation for Hypotensive Patients with Penetrating Torso Injuries. N Engl J Med. 1994;331:1105-9. Doi: 10.1056/NEJM199410273311701.

44. Dutton R, Mackenzie C, Scalea T. Hypotensive resuscitation during active hemorrhage: impact on inhospital mortality. J Trauma. 2002;52:1141-6. 
Prehospital Damage Control: The Management of Volume, Temperature... and Bleeding!

45. Qureshi SH, Rizvi SI, Patel NN, Murphy GJ. Meta-analysis of colloids versus crystalloids in critically ill, trauma and surgical patients. Br J Surg. 2016;103:14-26. Doi: 10.1002/bjs.9943.

46. Perel P, Roberts I, Ker K. Colloids versus crystalloids for fluid resuscitation in critically ill patients. Cochrane Database Syst Rev. 2013; 28(2):CD000567. Doi: 10.1002/14651858.CD000567.pub6.

47. Bulger EM, May S, Kerby JD, Emerson S, Stiell IG, Schreiber MA, et al. Out-of-hospital hypertonic resuscitation after traumatic hypovolemic shock: A randomized, placebo controlled trial. Ann Surg. 2011;253:431-41. Doi: 10.1097/SLA.0b013e3181fcdb22.

48. Delano MJ, Rizoli SB, Rhind SG, Cuschieri J, Junger W, Baker AJ, et al. Prehospital resuscitation of traumatic hemorrhagic shock with hypertonic solutions worsens hypocoagulation and hyperfibrinolysis. Shock. 2015;44:25-31. Doi: 10.1097/SHK.0000000000000368.

49. Bilotta F, Rosa G. Saline or albumin for fluid resuscitation in traumatic brain injury. N Engl J Med. 2007;357:2635. Doi: 10.1056/nejmc072827.

50. Boer C, Bossers SM, Koning NJ. Choice of fluid type: physiological concepts and perioperative indications. Br J Anaesth. 2018;120:384-96. Doi: 10.1016/j.bja.2017.10.022.

51. Santry HP, Alam HB. Fluid resuscitation: Past, present, and the future. Shock. 2010;33:229-41. Doi: 10.1097/SHK.0b013e3181c30f0c.

52. Murad MK, Issa DB, Mustafa FM, Hassan HO, Husum H. Prehospital trauma system reduces mortality in severe trauma: A controlled study of road traffic casualties in Iraq. Prehosp Disaster Med. 2012;27:36-41. Doi: 10.1017/S1049023X11006819.

53. Albreiki M, Voegeli D. Permissive hypotensive resuscitation in adult patients with traumatic haemorrhagic shock: a systematic review. Eur J Trauma Emerg Surg. 2018;44:191-202. Doi: 10.1007/s00068-017-0862-y.

54. Tremblay LN, Rizoli SB, Brenneman FD. Advances in fluid resuscitation of hemorrhagic shock. Can J Surg. 2001;44:172-9.

55. Ramesh GH, Uma JC, Farhath S. Fluid resuscitation in trauma: What are the best strategies and fluids? Int J Emerg Med. 2019;12:10-5. Doi: 10.1186/s12245-019-0253-8.

56. Holte K, Sharrock NE, Kehlet $\mathrm{H}$. Pathophysiology and clinical implications of perioperative fluid excess. $\mathrm{Br} \mathrm{J}$ Anaesth. 2002;89:622-32. Doi: 10.1093/bja/aef220.

57. Feinman M, Cotton BA, Haut ER. Optimal fluid resuscitation in trauma: Type, timing, and total. Curr Opin Crit Care. 2014;20:366-72. Doi: 10.1097/MCC.0000000000000104.

58. Myburgh JA, Mythen MG. Resuscitation fluids. N Engl J Med. 2013;369:1243-51. Doi: 10.1056/ NEJMra1208627.

59. Schnüriger B, Inaba K, Wu T, Eberle BM, Belzberg H, Demetriades D. Crystalloids after primary colon resection and anastomosis at initial trauma laparotomy: Excessive volumes are associated with anastomotic leakage. J Trauma. 2011;70:603-10. Doi: 10.1097/TA.0b013e3182092abb.

60. Brandstrup B, Tønnesen H, Beier-Holgersen R, Hjortsø E, OØrding H, Lindorff-Larsen K, et al. Effects of Intravenous Fluid Restriction on Postoperative Complications: Comparison of Two Perioperative Fluid Regimens - A Randomized Assessor-Blinded Multicenter Trial. Ann Surg. 2003;238:641-8. Doi: 10.1097/01. sla.0000094387.50865.23.

61. Duchesne JC, McSwain NE, Cotton BA, Hunt JP, Dellavolpe J, Lafaro K, et al. Damage control resuscitation: The new face of damage control. J Trauma. 2010;69:976-90. Doi: 10.1097/

TA.0b013e3181f2abc9. 
62. Cotton BA, Jerome R, Collier BR, Khetarpal S, Holevar M, Tucker B, et al. Guidelines for prehospital fluid resuscitation in the injured patient. J Trauma. 2009;67:389-402. Doi: 10.1097/TA.0b013e3181a8b26f.

63. Wang HE, Callaway CW, Peitzman AB, Tisherman SA. Admission hypothermia and outcome after major trauma. Crit Care Med. 2005;33:1296-301. Doi: 10.1097/01.CCM.0000165965.31895.80.

64. Martin RS, Kilgo PD, Miller PR, Hoth JJ, Meredith JW, Chang MC. Injury-associated hypothermia: An analysis of the 2004 National Trauma Data Bank. Shock. 2005;24:114-8. Doi: 10.1097/01. shk.0000169726.25189.b1.

65. Wandling MW, Nathens AB, Shapiro MB, Haut ER. Police transport versus ground EMS: A trauma systemlevel evaluation of prehospital care policies and their effect on clinical outcomes. J Trauma Acute Care Surg. 2016;81:931-5. Doi: 10.1097/TA.0000000000001228.

66. Demetriades D. Paramedic vs Private Transportation of Trauma Patients. Arch Surg. 1996;131:133. Doi: 10.1001/archsurg.1996.01430140023007.

67. Ordoñez CA, Rodríguez F, Parra M, Herrera JP, Guzmán-Rodríguez M, Orlas C, et al. Resuscitative endovascular balloon of the aorta is feasible in penetrating chest trauma with major hemorrhage: Proposal of a new institutional deployment algorithm. J Trauma Acute Care Surg. 2020;89:311-9. Doi: 10.1097/ ta.0000000000002773.

68. Ordoñez CA, Parra M, Caicedo Y, Padilla N, Rodriguez F, Serna JJ, et al. REBOA as a New Damage Control Component in Hemodynamically Unstable NTCH patients. Colomb Med (Cali) 2020; 51(4): e4064506. Doi: $10.25100 / c m . v 51$ i4.4506. 